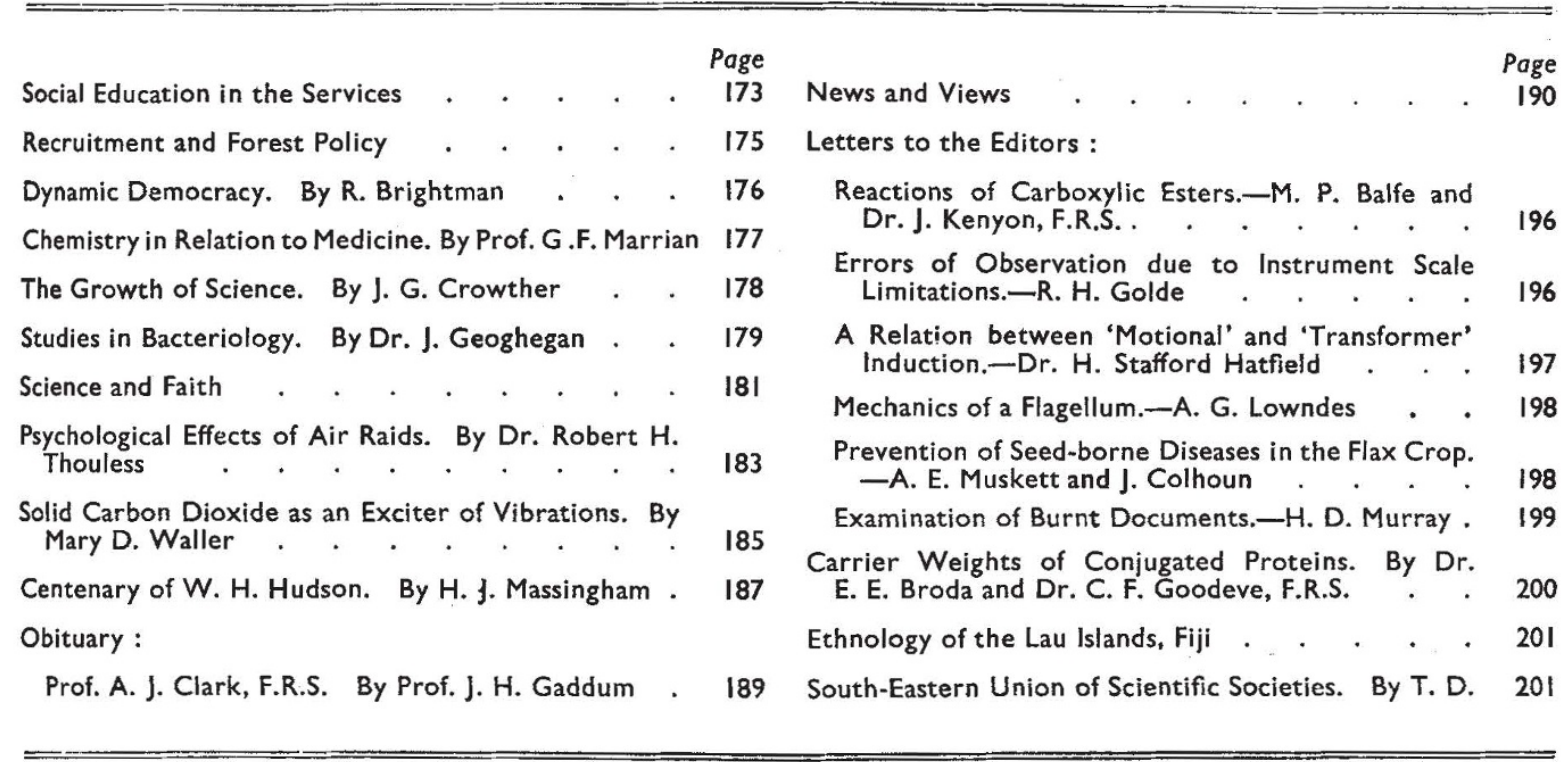

\title{
SOCIAL EDUCATION IN THE SERVICES
}

A GOOD deal has been said and written in recent weeks about education in the Forces, or the lack of it. It is generally agreed that something needs to be done, although there may be considerable difference of opinion as regards steps which might be taken.

Among the often conflicting evidence, particular weight must be attached to that of the men most concerned, namely those actually in the Forces. Among officers the complaint has been heard that army education is virtually non-existent, and men in the ranks have been heard to tell the same story. There are graduates in the ranks who will vouch that repeated inquiries after lectures have had no effect, and cases are even known of names having actually been collected for lectures which never materialized. Much of the complaint must, of course, be discounted as unavoidable. In addition to the static units, there are mobile units which are liable to very frequent removal about the country-side, and even the so-called static units must of necessity be moved on occasion. Removals such as these will naturally render more difficult the organization of army education, but they are scarcely an excuse for the conditions obtaining in some units.

There have been suggestions that the whole educational work of the armed forces should be organized on a compulsory basis, and recently there have been moves in this direction as regards one particular range of subjects. But in general the military authorities insist that the attendance of the men must be voluntary. Here a distinction must be made between the different types of instruction available. There are the purely training lectures, which, of course, must necessarily be compulsory. Then there are what may for convenience be termed vocational lectures, in subjects not directly connected with immediate military necessity, but likely to be of pecuniary advantage to the men on their return to civil life. Here, however, we are concerned much more with 'interest' lectures of no immediate military concern and of no likely financial advantage. Many people will be found to say that to take men away from their civil life and conscript them for military service, and then to hesitate to take an occasional hour of their free time for a lecture, is to swallow a whale and strain at a gnat. But there will be general agreement with the official view that men should not be forced to attend non-military lectures.

There is, however, among the men a considerable demand for voluntary lectures of this nature. Organizations, whose function it is to arrange lectures in different parts of the country for the civil population, report that men in uniform attend their lectures in considerable numbers, 
although there is clearly not a trace of compulsion to do so. In fact, in some areas it has been known that the uniformed members of the audience have outnumbered the civilians. A major distinction exists in this respect between the three services. In general, shore naval establishments are so busy with purely instructional work that the men have neither time nor inclination for further lectures, and to a lesser degree the same is true of the Royal Air Force. But this is by no means true of the army. Vast numbers of men do not know what to do with their spare time. Granted that a certain amount of leisure is wisely spent.on amusement, there still remains too much time on hand during which men would gladly be occupied. This state of affairs must inevitably lead to boredom, and one would expect it to be of major concern to the military authorities.

The main difficulty seems to be that although there is this desire among the men for lectures, the official machinery for translating the desire into the lecture does not in many cases function. Its efficiency, of course, varies much from unit to unit. Where the education officer is a man with his heart in his educational work, the possibility of organizing interest lectures will not merely be brought cursorily to the men's notice by occasional announcement or poster, but will be impressed continuously and actively upon them, and it will be emphasized that any request for a lecture will be listened to sympathetically and, where at all possible, granted. The crux of the matter is this need for the initiative to come from the ranks.

There is no doubt that a really determined seeker after enlightenment, who is prepared to persuade a few comrades to support him, can make it rather difficult for an education officer of a unit to refrain from arranging lectures. But is it fair to expect men to take such steps? And can we not readily understand if men feel that it may not react to their advantage to act in this way? Surely it should not be necessary for the provision of cultural lectures to depend upon the presence in a unit of men of rather exceptional initiative. It might be possible, for example, while retaining to the full the voluntary nature of the men's attendance, for education officers themselves to arrange attractive lectures for the men as an experiment. If as a result of experience it were found that men would not attend, other methods would have to be adopted. But all the evidence suggests that many would be glad of the opportunity of spending some of their spare time in this way.

There must be many bodies, national as well as local, which are able and willing to undertake interest lectures to the forces. On the biological side, such topics may be suggested as the human applications of biology, some of which are capable of presentation in a way directly concerned with the ideological struggle in which the men are engaged. The Nazi myth of an Aryan race of supermen, for example, could be used as a basis for anthropological lectures. Then there are all the problems of the history and development of the family, the entrancing subjects of evolution and heredity, in which there is widespread interest. On the physical and chemical side, the possibilities of dealing with applications are equally numerous, though care would of course have to be exercised to avoid making such lectures appear to be supplementary to instructional lectures at which attendance is compulsory; nevertheless, we believe that many soldiers would be quick to perceive the value of knowledge acquired by this means in their military duties. Geology should also provide good topics. A moment's consideration will show that outside the sciences also there are numerous opportunities of engaging interest. There is a far too common tendency to underestimate the intellectual level of the men in the Forces. It seems often to be assumed that so soon as a man dons khaki, he puts away all his normal mental interests and becomes a mere number. The army to-day is a fair cross-section of the younger civil population, and will have the same interests and intellectual level.

If, as is to be hoped, lectures become more easily available to the men, there will be a demand for lecturers which cannot be met from normal resources, and that will present to scientific men and others an opportunity to perform a most valuable piece of service to their fellows. There must be many who, under competent organizations, could give useful lectures; this applies with particular force to teachers, who have the vitally necessary training in presenting subjects in a simple and intelligible form. Moreover, there must be at present, in the armed forces themselves, large numbers of men who are excellently qualified to carry on this work.

It seems to be overlooked by those in authority that the present army is a body of citizens who are being trained for the purpose of defeating a specific enemy. It is not, and indeed cannot be, an army of professional soldiers. This is not meant in any disparaging sense, but solely to emphasize that the great majority of the men now serving are temporary soldiers, each of whom is looking forward to the time when, having defeated Nazism by force of arms, he can return to civilian life. He is entitled to expect that he shall be afforded opportunities of fitting himself to take his part as an earnest citizen in building up a new and better world order, and are only waiting for an opportunity to do so. 